\title{
IMPLIKASI DAN ARAH KEBIJAKAN PEMBERIAN ANGGARAN APBN/APBD UNTUK OPERASIONAL PENGELOLA ZAKAT DALAM MENINGKATKAN FUNGSI PEMERINTAH
}

\section{CUCU SOLIHAH \\ Pascasarjana Ilmu Hukum Universitas Suryakancana}

Email : cucusolihah2012@gmail.com

\begin{abstract}
The commitment in building Indonesia as a prosperous country gives consequence to the role of government in prospering the community. It is conducted by empowering the programs having potency of financial sources for developing this state. Beside the tax as the financial source of state development, the government enforces the policy of zakat management. The policy is the act number 23 in 2011 concerning zakat management in which the fund derives from the national / regional budget. In this case, the national or regional zakat council manages the zakat management. It is expected, it can help the process of state development and be a media in improving the social welfare as one of the government's roles.
\end{abstract}

Keywords: Government, National Zakat Council, National / Regional Budget, Welfare

\section{PENDAHULUAN}

Negara mempunyai tanggung jawab untuk melaksanakan amanat konstitusi, salah satu ketentuan yang terdapat dalam konstitusi UUD 1945 adalah ketentuan Pasal 34 ayat (1) berbunyi bahwa Fakir miskin dan anak-anak terlantar dipelihara oleh negara, dan ayat (2) nya berbunyi bahwa Negara mengembangkan sistem jaminan sosial bagi seluruh rakyat dan memberdayakan masyarakat yang lemah dan tidak mampu sesuai dengan martabat kemanusiaan.

Orientasi dan sasaran peningkatan kesejahteraan khususnya bagi fakir miskin dan anak-anak terlantar senada dengan sasaran penerima ( Mustahik) zakat, dari 8 (delapan) asnaf yang ditetapkan syariah Islam, sehingga tidak keliru jika kebijakan pemerintah memberikan ruang khusus bagi pengelolaan zakat yang dikelola oleh BAZNAS dengan memberikan anggaran negara baik APBN untuk BAZNAS Pusat maupun APBD untuk BAZNAS Kabupaten/Kota di Indonesia.

Sementara itu, potensi zakat dalam rangka memberikan wewenang kepada pemerintah bertindak sebagai operator atau pelaksana. Alasannya Pertama, pemungutan zakat dapat dipaksakan berdasarkan Qur'an Surah At-Taubah : 103. Padahal satu-satunya lembaga yang mempunyai otoritas untuk melakukan pemaksaan seperti itu adalah negara lewat perangkat pemerintahan seperti halnya pajak. Apabila hal ini disepakati maka zakat akan menjadi salah satu sumber penerimaan negara. Kedua, potensi zakat yang dikumpulkan dari masyarakat amat besar. Menurut hasil penelitian Pusat Bahasa dan Budaya UIN Syarif Hidayatullah dan Ford Foundation tahun 2005 mengungkapkan, jumlah potensi filantropi (kedermawanan) umat Islam Indonesia mencapai 19,3 trilyun pertahun. Saat ini zakat belum berfungsi sebagai regulator, akibatnya jumlah orang miskin di Indonesia selalu meningkat, sementara zakat bertujuan untuk mengurangi kemiskinan.

Dalam posisi BAZNAS sebagai lembaga pengelola zakat yang juga penerima APBN/APBD maka BAZNAS dituntut untuk melaksanakan program peningkatan kesejahteraan dan penanggulangan kemiskinan di Indonesia sebagai kompensasi 
atas anggaran negara yang diterimanya secara terstruktur dan terukur keberhasilannya.

\section{METODE PENELITIAN}

Penelitian ini menggunakan pendekatan normatif yuridis yang berupa analisis deskriptif. Sumber data yang digunakan adalah data primer yang berupa wawancara dengan pengelola di Badan Amil Zakat Nasional (BAZNAS), dan Komisi VIII DPR RI. Data sekunder yang berupa data primer berupa peraturan perundangundangan, seperti Undang-undang No. 23 Tahun 2011 tentang Pengelolaan Zakat dan Peraturan Pemerintah No. 14 Tahun 2014 Tentang Pengelolaan zakat. Adapun Teknik pengumpulan data diambil dari Kementerian Agama RI dengan analisi datanya menggunakan data triangulasi.Metode analisis dilakukan melalui proses interpretasi, yaitu mencoba menerobos dan menangkap makna dari data yang diperoleh, dan kemudian dilakukan evaluasi kritis dan menyajikan pandangan alternatif yang lebih lengkap serta sesuai.

\section{HASIL DAN PEMBAHASAN}

\section{A. Arah Kebijakan Pengelolaan Zakat Terhadap Tujuan Dan Fungsi Pemerintah.}

Kesejahteraan yang menjadi tujuan kehidupan berbangsa harus diwujudkan dalam pondasi sistem ekonomi nasional dan dalam implementasi pengembangan ekonominya harus berdasarkan pada cita hukum ekonomi nasional untuk sebesar-besarnya kemakmuran rakyat dan penataan sistem hukum yang berpihak kepada rakyat, terlebih tujuan pembangunan secara mikro adalah dalam rangka mewujudkan suatu masyarakat adil dan makmur yang merata materiil dan spritual berdasarkan Pancasila di dalam wadah Negara Kesatuan Republik Indonesia (NKRI) yang merdeka, berdaulat, bersatu dan berkedaulatan rakyat, dalam suasana peri kehidupan bangsa yang aman, tenteram, tertib, dan dinamis serta dalam lingkungan pergaulan dunia yang merdeka, bersahabat, tertib dan damai.

Berbeda dengan faham kapitalisme/ liberalism menganut asas perseorangan (asas individualism) yang lahir dari pemikiran bahwa manusia (individu) itu dilahirkan bebas, terpisah satu sama lain dan masingmasing dengan penuh kekuasaan.

Sehubungan dengan hal tersebut, pengembangan sistem ekonomi Indonesia tidak berorientasi pada faham kafitalisme mupun sosialis, karena kedua sistem ini cenderung mengarah pada sistem perekonomian yang memberikan kebebasan secara penuh kepada setiap orang untuk melaksanakan kegiatan perekonomian dan setiap warga dapat mengatur nasibnya sendiri sesuai dengan kemampuan dan bebas bersaing dalam bisnis untuk memperoleh laba sebesarbesarnya dan semua orang bebas melakuan kompetisi untuk memenangkan persaingan bebas dengan berbagai cara, sehingga faham tersebut tidak sesuai dengan prinsip arah pengembangan sistem ekonomi nasional.

Berpijak dari konsep negara kesejahteraan memberi ruang kepada negara atau pemerintah dengan tidak semata-mata sebagai penjaga keamanan atau ketertiban masyarakat, tetapi memikul tanggung jawab utama untuk mewujudkan keadilan sosial, kesejahteraan umum, dan sebesar-besarnya kemakmuran rakyat.

Negara sejahtera (welfare state) merupakan konsep pemerintahan yang menempatkan negara sebagai pemegang kunci utama untuk melindungi dan meningkatkan ekonomi dan kesejahteraan rakyatnya. Konsep tersebut dijalankan atas dasar prinsip-prinsip pemerataan dalam kesempatan dan distribusi kekayaan, serta tanggung jawab pemerintah (negara) untuk menyediakan pelayanan minimal bagi kelompok masyarakat tidak mampu dan rentan.

Ketentuan Pasal 33 UUD 1945 secara subtansi terkandung di dalamnya sistem demokrasi ekonomi, produksi dikuasai oleh semua, sehingga perekonomian disusun 
sebagai usaha bersama berdasarkan atas asas kekeluargaan, dan semangat untuk mewujudkan keadilan sosial terpancar di dalam Pasal 34 yang mengatur mengenai fakir miskin dan anak-anak terlantar dipelihara oleh negara. Kesejahteraan yang menjadi tujuan pembangunan nasional harus menjadi prioritas utama, dengan meningkatkan kesejahteraan masyarakat dan untuk mewujudkannya sangat tergantung dari kemampuan untuk dapat lepas dari jerat krisis dan membangun fundamental ekonomi yang lebih mandiri.

Perspektif sejarah dan arah mengenai perekonomian Indonesia diusulkan oleh Muhammad Hatta, sebagai berikut :

a. Orang Indonesia hidup dalam tolong menolong

b. Tiap-tiap orang Indonesia berhak mendapatkan pekerjaan dan mendapat penghidupan yang layak bagi manusia. Pemerintah menganggung dasar hidup minimum bagi seseorang

c. Perekonomian disusun sebagai usaha bersama menurut dasar kolektif

d. Tanah dan kepunyaan masyarakat, orang seorang berhak memakai tanah sebanyak yang perlu baginya sekeluarga

e. Harta milik orang-seorang tidak boleh menjadi alat penindas orang lain

f. Fakir dan miskin diperlihara oleh Pemerintah.

Penegasan arah pencapaian tujuan masyarakat adil, makmur dan sejahtera, diwujudkan dalam suatu pondasi ekonomi Pancasila dengan semangat kebersamaan dan keadilan, melalui perwujudan konsep negara kesejahteraan yang terealisasi dalam alokasi sumber dana yang bersumber dari keuangan negara untuk membiayai program-program pembangunan yang memberi dampak terhadap upaya mensejahterakan masyarakat, salah satunya pemberian anggaran APBNAPBD untuk operasional lembaga pengelola zakat bentukan Pemerintah yakni BAZNAS.

\section{B. Mengelola Zakat dan Peran Negara Untuk Mewujudkan Kesejahteraan Masyarakat}

Islam memiliki solusi untuk

menanggulangi kemiskinan dan

meningkatkan kesejahteraan melalui zakat.

Zakat diharapkan mampu memenuhi

kebutuhan dasar manusia dengan terciptanya kesejahteraan ekonomi yang seimbang dengan tidak menumbuhkan kecemburuan yang semakin menajam antara kaum kaya dan golongan ekonomi lemah (miskin) dengan menciptakan kesejahteraan dan iklim solidaritas sesama manusia.

Dalam melaksanakan tugas yang diberikan Undang-undang kepada lembaga pengelola zakat yakni BAZNAS, maka undang-undang menentukan bahwa untuk operasional pelaksanaan tugas dan fungsi BAZNAS dibiayai dengan Anggaran Pendapatan dan Belanja Negara dan Hak Amil sebagaimana ketentuan Pasal 30 dan lebih lanjut ditegaskan dalam Pasal 31 Undang-Undang No. 23 Tahun 2011 Tentang Pengelolaan Zakat.

BAZNAS dikatagorikan sebagai lembaga non struktural dan bersifat lembaga nirlaba penerima anggaran yang bersumber dari APBN/APBD. Berdasarkan surat keputusan Menteri Keuangan RI No. 792 Tahun 19990 menyatakan bahwa lembaga keuangan adalah semua badan usaha yang kediatannya di bidang keuangan melakukan penghimpunan dana, penyaluran dana kepada masyarakat terutama dalam membiayai investasi pembangunan dan jika dilihat dari sifat operasinya, suatu lembaga atau organisasi dapat dibagi menjadi dua macam, pertama lembaga yang berorientasi untuk mendapatkan keuantungan (profit institution), kedua lembaga yang dalam menjalankan aktivitasnya tidak berorientasi mengumpulkan keuntungan (non-for- profit institution) atau organisasi nirlaba. Kelangsungan organisasi nirlaba ssangat tergantung dari berbagai 
sumbangan yang diberikan oleh pihak-pihak yang percaya kepada organisasi tersebut.

Lebih lanjut ketentuan Pasal 67 ayat (1) Peraturan Pemerintah No. 14 Tahun 2014 berisi ketentuan bahwa biaya operasional BAZNAS dibebankan pada anggaran pendapatan dan belanja negara dan hak amil. Sementara itu dalam hal biaya operasional dan hak amil untuk LAZ maka Pasal 32 menentukan bahwa LAZ dapat menggunakan hak amil untuk membiayai kegiatan operasional.

Selain hal tersebut di atas Pasal 70 Peraturan Pemerintah No. 14 Tahun 2014 Tentang Pengelolaan zakat menentukan bahwa: "Pembiayaan yang diperuntukan bagi operasional BAZNAS yang bersumber dari anggaran pendapatan dan belanja negara dapat diberikan kepada BAZNAS Provinsi dan BAZNAS Kabupaten/Kota apabila pembiayaan operasional yang bersumber dari anggaran pendapatan dan belanja daerah tidak mencukupi.

Namun demikian sekalipun ada ruang penambahan anggaran untuk biaya operasional dan hak amil tetapi BAZNAS Provinsi dan BAZNAS Kabupaten/Kota belum pernah mengajukan atas kekurangan dana untuk biaya operasional dan hak amil mengingat anggaran dari Pemerintah Daerah Provinsi dan pemerintah Kabupaten selama ini telah cukup menutupi kebutuhan untuk biaya operasinal dan hak amil karena setiap biaya yang akan diajukan disesuaikan dengan rencana kerja dan anggaran tahunan yang disusun oleh BAZNAS Provinsi atau Kabupaten/Kota dan disahkan oleh BAZNAS untuk mendapat pengesahan dari DPRD Provinsi dan DPRD Kabupaten/Kota, sementara bagi BAZNAS setiap pengajuan anggaran berdasarkan rencana kerja dan anggaran tahunan yang disahkan oleh Menteri.

Pertanggungjawaban keuangan yang dipergunakan untuk operasional dan hak amil yang dipergunakan oleh BAZNAS Pusat, Provinsi dan Daerah yang bersumber dari keuangan negara (APBN, APBD) terdapat mekanisme berbeda antara BAZNAS pusat dengan BAZ daerah Provinsi dan Kabupaten/Kota, dimana BAZNAS Pusat mendapat bagian anggaran negara dari APBN merupakan bagian dari anggaran kementerian Agama, karena dalam hal zakat kementarian agama berkedudukan sebagai legislator dan BAZNAS sebagai eksekutor.

Mekanisme pertanggungjawaban penggunaan anggaran negara yang dipergunakan untuk biaya operasional sebagaimana tersebut di atas,tidak terlepas dari sistem administrasi keuangan yang terdiri dari serangkaian langkah-langkah dimana dana-dana disediakan bagi pejabat-pejabat tertentu di bawah prosedur yang akan menjamin sah dan berdaya-gunanya pemakaian dana-dana itu, Bagian utama ialah menyusun anggaran belanja, pembukuan, pemeriksaan, pembukuan. Anggaran belanja adalah perkiraan pengeluaran dan penerimaan yang seimbang untuk suatu waktu tertentu.

Semantara itu terhadap BAZNAS Provinsi dan Kabupaten/Kota keuangan yang akan dipergunakan untuk biaya operasional/hal amil diperoleh dari APBD Pemerintah Daerah yang membidangi masalah keagamaan (Kesra) di tingkat Provinsi dan Daerah Kabupaten/Kota melalui sistem pengajuan anggaran berbasis keperluan sehingga pelaporannyapun disampaikan kepada Gubernur/Bupati sebagaimana Pasal 34 (2) UU No. 23 Tahun 2011 dan Pasal 71 (1) Peraturan Pemerintah No. 14 Tahun 2014 Tentang Pengelolaan zakat.

Sehubungan dengan BAZNAS Kabupaten/Kota, mendapat anggaraan APBD dari pemerintah Daerah, maka konsekwensinya pertanggungjawaban dan pengawasan dilaksanakan oleh Pemerintah Daerah. Berikut merupakan gambaran sumber penerimaan biaya operasional dan hak amil dari BAZNAS dan LAZ 


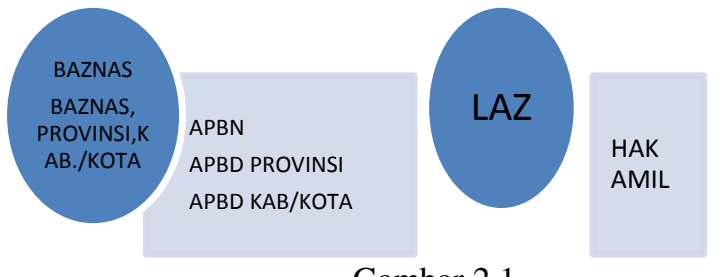

Gambar 2.1

Biaya operasional dan Hak Amil BAZNAS dan LAZ Sumber : disarikan dari Pasal 30-33 UU No. 23 Tahun 2011 Tentang Pengelolaan Zakat

Berdasarkan ketentuan tersebut di atas, maka BAZNAS sebagai salah satu lembaga pemerintah non struktural penerima APBN bertanggung jawab kepada Kementerian Agama RI, sekaligus sebagai lembaga pengelola zakat yang mendapat bagian dari keuangan negara yang bersumber dari APBN dan/atau APBD.

Dalam tataran praktis tugas dan fungsi pengelola zakat khususnya BAZNAS sebagai penerima anggaran negara, tidak diberikan kewajiban-kewajiban mengikat dalam suatu peraturan perundang-undangan sebagai bentuk timbal balik dari hak keuangan negara yang diperolehnya. BAZNAS hanya diberikan ketentuan untuk melaporkan (menyampaikan) dan mempertanggung jawabkan laporan pelaksanaan pengelolaan zakat,infak dan sedekah dan dana sosial keagamaan lainnya sesuai dengan hierarkis pemerintahan (Kementerian Agama, DPR RI dan juga Presiden) gubernur dan juga Bupati secara periodik ( 6 bulan dan setiap akhir tahun) juga diberikan tugas untuk menerima laporan pelaksanaan pengelolaan zakat,infak dan sedekah dan dana sosial keagamaan lainnya dari LAZ meskipun tidak semua LAZ yang telah mendapat ijin operasional memberikan laporannya kepada BAZNAS.

Gambaran

sistem

pertanggungjawaban pengelolaan zakat sebagaimana tersebut di atas, memberikan arah birokrasi, meskipun belum dilaksanakan secara ideal yang menjadi sarana untuk pencapaian cita-cita ideal suatu bangsa dan negara dalam upaya menyelenggarakan kesejahteraan masyarakatnya. Idealnya suatu sistem birokrasi adalah bertugas menghubungkan kepentingan negara dan masyarakat dengan suatu komitmen pelayanan yang terus meningkat dari waktu ke waktu.

Sistem birokrasi yang dimaksud memberi arah terhadap hak dan kewajiban antara negara sebagai suatu lembaga yang mempunyai tugas melaksanakan konstitusi, khususnya Pasal 34 UUD 1945, dipihak lain adanya hak masyarakat untuk menikmati kesejahteraan, maka untuk menjembatani dua kepentingan tersebut dibuatlah lembagalembaga baik struktural Pemerinah maupun non struktural pemerintah yang bertugas untuk membantu tugas-tugas negara.

Kebijakan Pemerintah dengan memberikan anggaran negara bagi operasional lembaga non struktural BAZNAS berimplikasi terhadap sistem pengelolaan zakat yang baik (professional dan akuntabilitas) sehingga diharapkan akan menjadikan zakat menjadi instrument meningkatan kesejahteraan dan penanggulangan kemiskinan, dan zakat akan menjadi sumber dana potensial yang dapat dimanfaatkan untuk memajukan kesejahteraan umum bagi seluruh masyarakat.

\section{KESIMPULAN}

Berdasarkan kajian sebagaimana tersebut di atas, terdapat kesamaan tugas dan fungsi pemerintah dengan fungsi lembaga pengelola zakat BAZNAS dalam upaya meningkatkan kesejahteraan masyarakat dan menanggulangi kemiskinan, sehingga konsekwensinya Negara dituntut mampu mewujudkan keberpihakan terhadap masyarakat melalui program-program peningkatan kesejahteraan masyarakat melalui sistem jaminan sosial sehingga setiap individu harus mendapat penghidupan yang layak dari negara.

Pemberian anggaran keuangan yang bersumber dari APBN/APBD mengindikasikan tanggungjawab Pemerintah dengan memberikan anggaran yang diperuntukan bagi biaya operasional 
pengelolaan zakat (BAZNAS) sekaligus terkandung hak pemerintah atas BAZNAS untuk melaksanakan fungsi pemerintah dalam hal meningkatkan kesejahteraan masyarakat secara terukur dan terorganisir dengan baik.

\section{DAFTAR PUSTAKA}

\section{Jurnal}

Cucu Solihah, Negara Sejahtera Dengan Memberdayakan Zakat Melalui Fungsionalisasi Sistem Ekonomi Islam Dan Hukum Administrasi Negara, Jurnal Hukum Mimbar Justitia, Vol. VI No. 01 Edisi januari-Juni 2014, Fakultas Hukum Universitas Suryakancana, Cianjur. ..., Implementasi Undang-Undang NO. 38 Tahun 1999 dan Perda Kabupaten Cianjur No. 7 Tahun 20004 Tentang pengelolaan zakat dalam meningkatkan kesejahteraan ekonomi kerakyatan di kabupaten Cianjur, Jurnal Hukum Vol. III Nomor 01 Mei-Oktober 2008, Fakulatas Hukum Universitas Suryakancana.

Dyah Esthi Perwitasari. “ Karakteristik Mustahik Dalam Penggunaan Dana ZIS Dan Pegnaruhnya Terhadap Probabitas Pengingkata Pendapatan Usaha ( Studi Kasus Mustahik Peserta Program Pemberdayaan Ekonomi LAZ PKPU”, Eksis Jurnal Ekonomi Keuangan Dan Bisnis Islami.Vol.4 No.2. April-Juni 2008, Jakarta : Kekhususan Ekonomi Dan Keuangan Syariah Program Studi Timur Tengah Dan Islam Program Pascasarjana UI.

Elli Ruslina, Pasal 33 Undang-Undang Dasar 1945 Sebagai Dasar Perekonomian Indonesia : Terjadi Penyimpangan Terhadap Konstitusi, Litigasi Jurnal Ilmu Hukum Vo. 12 No. 1 April 2011,FH Universitas Pasundan, Bandung.

Etty Rochaeti. "Analisis Mengenai Zakat Profesi Kaitannya Dengan Pajak
Penghasilan" Jurnal Wawasan Hukum, Vol.24 Nomor 1. Februari 2011,Bandung: Fakultas Hukum STHB. Gusfahmi, Rekontruksi Praktek zakat dan pajak untuk menanggulagi kemiskinan, Zakat \& Empowering Jurnal pemikiran dan gagasan vol. 2 Juni 209.IMZ, Ciputat,.

Mufidah, Sistem Hirarki Kelembagaan Badan Pengelola Zakat Di Indonesia (Tinjauan Pelaksanaan UndangUndang No. 23 Tahun 2011) Jurnal Cita Hukum, Vol. 4 No. 2 Desember 2016

Rini Irianti Sundari, Pelaksanaan Etika Birokrasi Dalam Penyelenggaraan Pemerintahan Di Indonesia, Scientica Jurnal Social Humaniora ( Hukum, Manajemen, Psikologi, pendidikan, komunikasi, Vol. I No. 1 Juni 2013,

\section{Buku}

Bagir Manan. Politik Perundang-undangan Dalam Rangka Mengantisipasi Liberalisasi Perekonomian, Fakuktas Hukum UNILA, Lampung, 1996.

DimocK \& Dimock. Adminstrasi Negara, Renika Cipta, Jakarta,1992.

Mubyarto. Sistem Dan Moral Ekonomi Indonesia. LP3ES. Jakarta. 1988.

Taufiq Effendi. Reformasi Birokrasi dan iklim Investasi.Konstitusi Press. Jakarta. 2013.

Yusuf Qaradhawi, Kiat Islam Mengentaskan Kemiskinan (Judul Asli : Musykilah AlFakr Wakaifa 'Aalajaha al-Islam), penerjemah : Syafril Halim, Jakarta : Gema Insani Press, 1995 